\title{
〈実績 発表〉
}

\section{北炭夕張炭砿におけるレンジングドラムカッ夕採炭について}

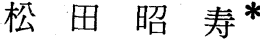

\section{1. 緒言}

当砝では昭和 38 年ドラムカッタを導入以来 3 年を以て 全切羽のドラム化を完了し， 1 日 4 サイクル $(2.8 \mathrm{~m} /$ 日 進行）が常態となった。しかし切羽が梁部に移行するに 伴々 10 尺上層は漸次炭丈が高くなり, 従来のハリネズミ 型では作業遅れによる1 日 4 サイクル達成が困難となっ た。

昭和 41 年 10 月よりアイコフ製レンジングドラムカッ 夕を導入し， 2 矿 2 区の切羽に使用し，習熟に伴い昭和 42 年 11 月以降 2 区左 3 上層ロングにおいて, 1 切羽 $42,676 \mathrm{t} /$ 月 (原炭) の成果を上げる事がでさた。以下そ の概要と固定式ドラムカッタとの比較を報告し, 諸賢の ご指導とご批判を仰ぐ次第である。。

\section{2. 炭 層 状 況}

1) 稼行炭層 (第 1 図参照)

当砿は，採炭区域を 3 区域に分け現在 6 切羽が稼行中 である。稼行炭層は 10 尺層と 10 尺上層（通常上層と呼 称）である。10 尺層は炭丈が $1.50 \mathrm{~m}$ あり上層の炭丈は $2.50 \mathrm{~m}$ で, 炭質は軟質（上層 Fb 40）で弱粘結炭である。

払稼行に際しては盤下にガス抜坑道を掘進し, 先進ガ ス抜ボーリングを実施している。払は上層を採掘後に

10 尺層を稼行し,レンジングドラムカッタは上層に使用 している。

2）上下盤の性状

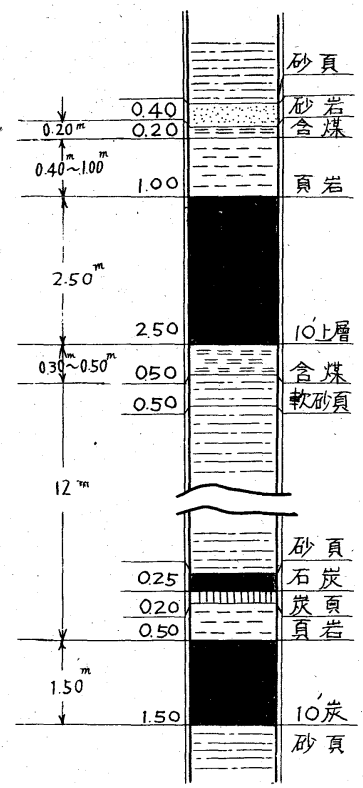

上層の直接天盤は $0.40 \mathrm{~m} \sim 1.0 \mathrm{~m}$ の軟質頁 岩で, その上に $0.20 \mathrm{~m}$ の含煤層があり，一見 して安定しているよら に見えるが，露出する と緩みやすく摺鉢状の 裂裂が発達し長時間放 置でをない。下盤は表 面に $0.30 \sim 0.50 \mathrm{~m}$ の含 煤があり鉄柱のめり込 みが激しんので，必ず 沈下防止盤を使用して いる。をたDCCトラフ が下盤に喰ら込んだり 移設中に含煤層を削り 無用の抵抗の原因とな っている。したがって 岸壁注水およびガス抜 ボーリングの水が流れ ると粘土状となるので， これらの保安作業は特 に慎重飞行なっている。 10 尺層は上層の約 12

第1図柱 状 図

$*$ 北海道炭矿汽船株式会社夕張矿業所
性状につんては省略する。

3) 断層の状況

切羽には $0.50 \sim 1.50 \mathrm{~m}$ の同じ方向に走る小断層が，常 に $1 \sim 2$ 本あるが岩質が軟質なので，発破で緩めてカッ⿻ タで切截している。断層の前後は天盤が不良なので, 先 行カッぺを上げて前打柱を施している。

\section{2 区左 3 上層ロングの概要}

1) 切羽の位置 (第 2 図参照)

幹線坑道の第 2 ベルト斜坑と第 2 排気斜坑を盤下に設 け，排気斜坑より払の盤下に各片のガス抜坑道を掘進し ている。上添坑道はガス抜抗道より材料昇を上げて着炭 させ，一片盤上の旧ゲートあるいはその梁側に作りゲー トはべルト斜坑よりポケットおよび入気昇を上げて着炭 させ左右に払を展開する前進式長壁法である。

2) 切羽諸元と払の規格（第1 表) (第3 図)

炭層の傾斜は約 18 度で, 切羽は真傾斜に設定している。 支保は $1.40 \mathrm{~m}$ カッペを使用した千鳥枠で，下ステーブル は格子枠としてんる。

\section{4. 使 用機 械}

1) レンジングドラムカッタ

アイコフ製レンジングドラムカッタの仕様は第 2 表の 通りである。第 4 図に示す通りカッターッドの面側にア 一ムがあり，その先端にドラムが取付けられている。ド

ラムはアームを支持している油圧ジャキの操作により 上下させる機構のものである。

第 5 図は切截時の状態であるが，切上りの時は天盤際 を切截し，切下り（押切り）の時は下盤際を切截し，同 時に積込を行なら機構になっている。

2)フイードチエン緊張装置

エアーシリンダー方式で, 原動部とリターン部に, 第 6 図のような装置をそれぞれ設置し，常時緩み側を緊張 させている。

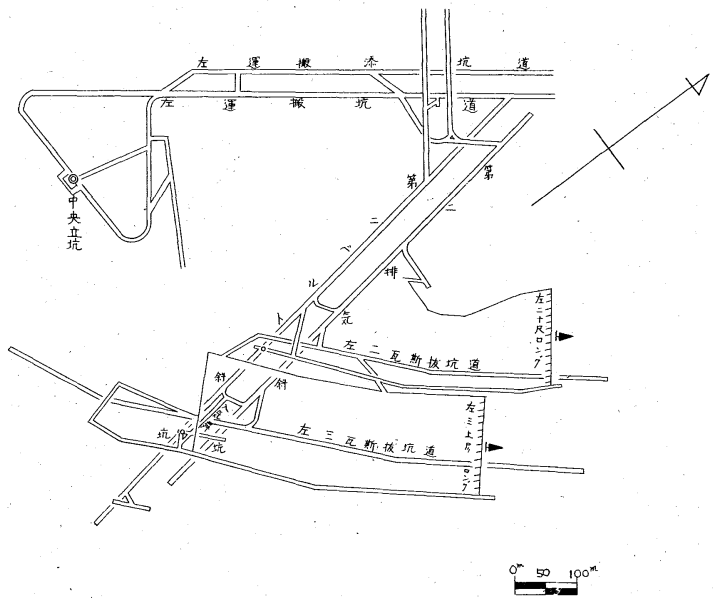

第2図。切羽位置図 


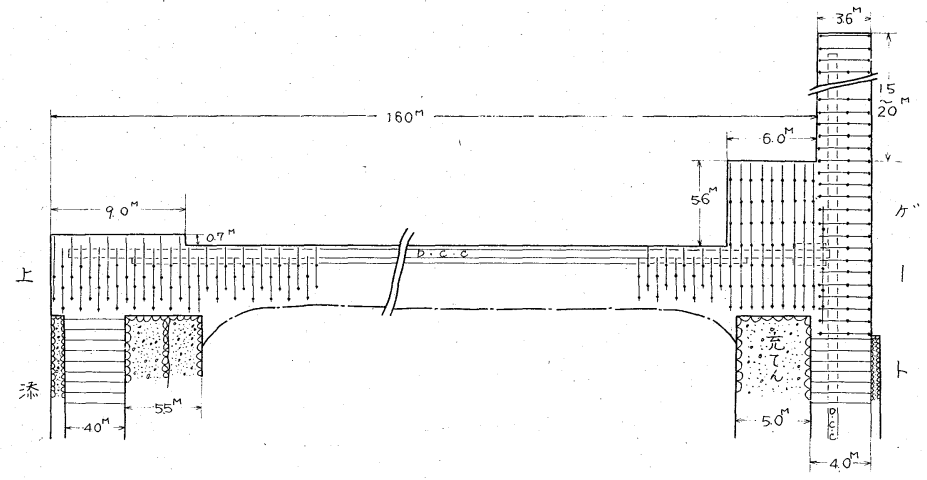

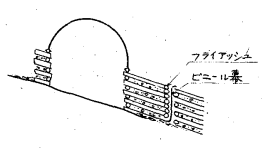

上添正面図

\section{第3 図}

払規格図

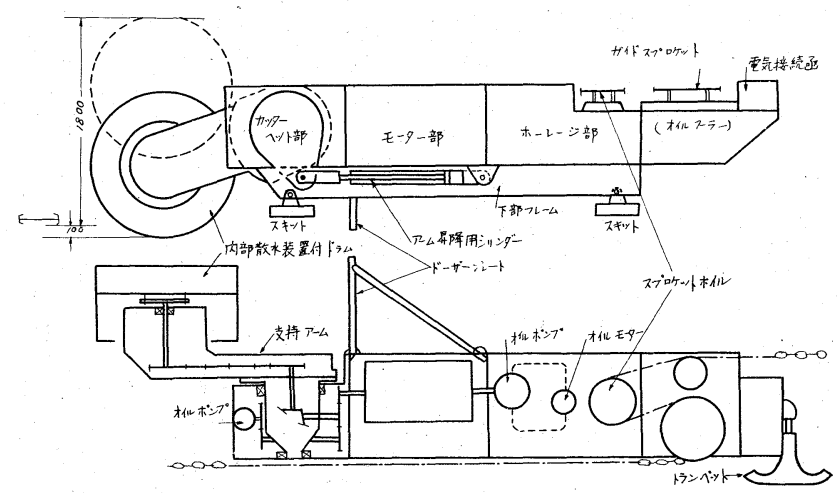

第1表 切 羽諸 元

\begin{tabular}{|c|c|c|c|}
\hline $\begin{array}{l}\text { 面 } \\
\text { 稼 } \\
\text { 深 } \\
\text { 進 } \\
\text { z }\end{array}$ & テーブ & $\begin{array}{l}\text { 長 } \\
\text { 丈 } \\
\text { 斜 } \\
\text { 度 } \\
\text { 行 } \\
\text { ル }\end{array}$ & $\begin{array}{l}160 \mathrm{~m} \\
2.50 \mathrm{~m} \\
18 \sim 20^{\circ} \\
-350 \mathrm{~m} \\
1.40 \mathrm{~m} / \text { 方 } \times 2 \text { 方 } / \text { 日 } \\
\text { 上 } 9.0 \mathrm{~m}, \text { 下 } 6.0 \mathrm{~m}\end{array}$ \\
\hline 保 & $\begin{array}{l}\text { 方 } \\
\text { 染 } \\
\text { 鉄 } \\
\text { 力 }\end{array}$ & \begin{tabular}{l|} 
式 \\
間 \\
柱 \\
○。
\end{tabular} & $\begin{array}{c}\text { 千鳥枠 (下ステーブル格子枠 }) \\
0.60 \mathrm{~m}(0.70 \mathrm{~m}) \\
\text { 日本鉱機・ダウティ型 } \\
\text { 大同 } 1.40 \mathrm{~m} \text { ピン型 }\end{array}$ \\
\hline $\begin{array}{l}\text { 跡 } \\
\text { 充 }\end{array}$ & & $\begin{array}{l}\text { 理 } \\
\text { L }\end{array}$ & $\begin{array}{l}\text { 総 バラ ラ } \\
\text { 上 } 5.50 \mathrm{~m} \text { 下 } 5.00 \mathrm{~m} \\
\text { 下ビニール幕フライアッシュサンド }\end{array}$ \\
\hline
\end{tabular}

第4図、レンジングドラムカッタ構造図

第 2 表 レンジングドラムカッタ仕様

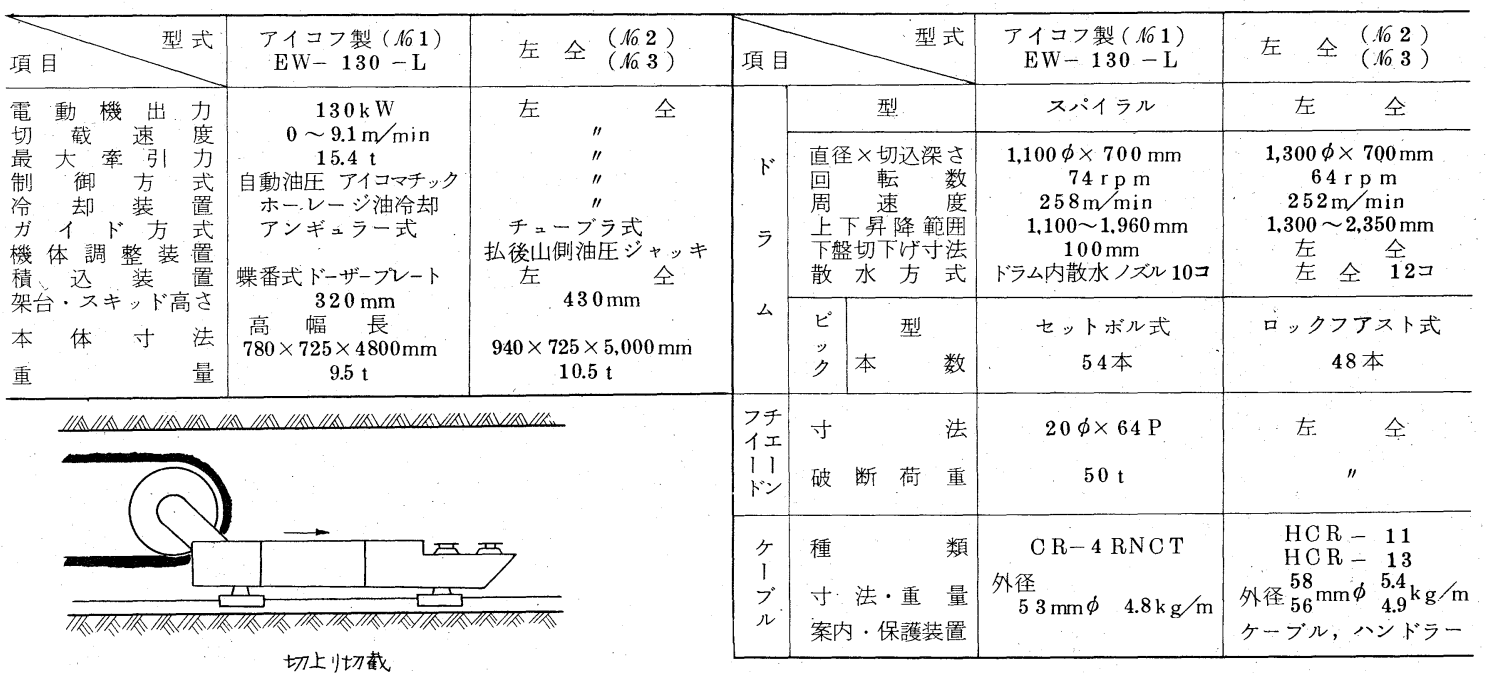

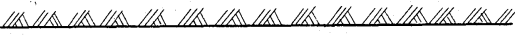

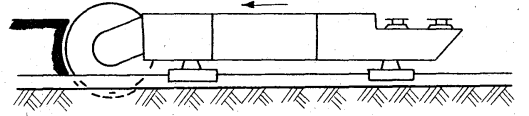

切下切截

第 5 図

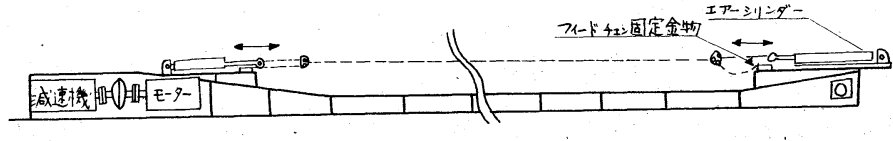

第6図フフイドチエン緊張装置取付図 
ドラムカツタ

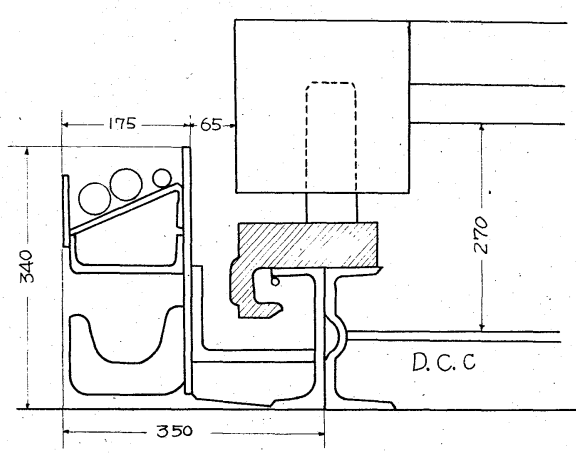

第 7図ー1「アンギュラガイド」

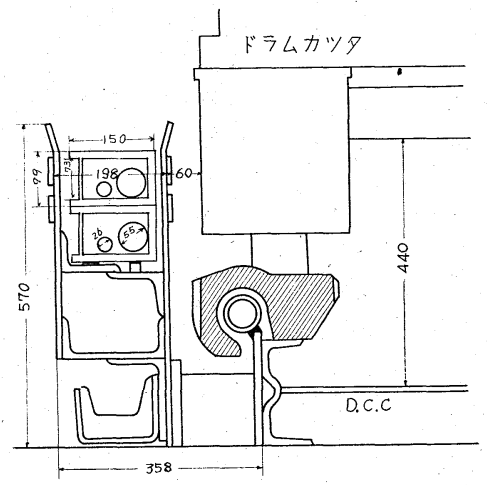

第 7図ー2「チューブラガイド」

3).脱線防止ブラケット

当初アンギュラーガイド方式（第 7 図-1）であった が，2号機よりチューブラガイド方式（第 7 図-2）を 採用している。

4) スピルプレート

第 7 図ー 1 のごとく幅広とし，傾斜板を付けている。 2 号機よりケーブルハンドラー（第 7 図一

2) とした。

\section{5) 運搬機}

払とゲートの運搬機仕様は第 3 表に示す。 払の下盤が軟弱なので，トラフ移設を開始 するとDC Cトラフが下盤飞喰ら込み過負 荷の原因となる事がしばしばあるので，払 の原動にウエストフアリヤ製 P F - 1 を使 用している。

C.壮高さ $260 \mathrm{~mm}$ のプレートを取付けて あり，スクレーパは $0.50 \mathrm{~m}$ 間隔とし，スピ ードを $45 \mathrm{~m} / \mathrm{min}$ スアップし，運炭量の増 加老図っている。

6) 移設用具

ニッチ製手動ジャッキ（推力 $2 \mathrm{t}$, ス卜 ローク $750 \mathrm{~mm}$ ) を $6 \mathrm{~m}$ どとに配置上, 原 動部には, 水圧シフタおよび $5 \mathrm{t}$ エアープ ロッグを使用している。

\section{5. 採 炭 方 法}

作業忙 1， 2 番方採岸とし, 各方共 2 サ イクル完全実施で，進行は 1 日 $2.80 \mathrm{~m}$ であ る。

人員配置は第 4 表に示す。天盤状態が前

第 3 表運搬機仕様

\begin{tabular}{|c|c|c|c|c|c|c|c|}
\hline 設置個所 & 種 類 & $x$ メー & 型 式 & 出 力 & $\begin{array}{l}\text { 速 度 } \\
\mathrm{m} / \mathrm{min}\end{array}$ & $\begin{array}{r}\text { 機長 } \\
\mathrm{m}\end{array}$ & . 考 \\
\hline 面 内 & D.C.C & $\begin{array}{l}\text { ウエスト } \\
\text { フアリヤ }\end{array}$ & PF-I & $42 \mathrm{~kW} \times 2$ & 39.0 & 160 & $\left\{\begin{array}{r}\text { スピルプレート } \\
\text { 高さ } 340 \mathrm{~mm} \\
\text { トラフ日立 } \\
54 \mathrm{~W} \text { 型 }\end{array}\right.$ \\
\hline ゲートN No.3 & D.C.C & 日立 & $53 \mathrm{H}$ & $40 \mathrm{~kW} \times 2$ & 45.0 & 50 & $\begin{array}{r}\text { イスクレーパ-間隔 } \\
500 \mathrm{~mm}\end{array}$ \\
\hline " No. 2 & B. $\mathrm{C}$ & 本 & $30 \mathrm{H}$ & $50 \mathrm{H}$ & 110.0 & 180 & \\
\hline " No.1 & B.C & 11 & $30 \mathrm{H}$ & $50 \mathrm{H}$ & 110.0 & 200 & \\
\hline マザー & D.C.C & 日立 & $53 \mathrm{H}$ & $30 \mathrm{~kW} \times 1$ & 31.8 & 30 & 側板高さ $600 \mathrm{~mm}$ \\
\hline
\end{tabular}

第 4 表 払人員配置表

\begin{tabular}{|c|c|c|c|c|c|}
\hline \multicolumn{2}{|c|}{ 項目 方別 } & 1 & 2 & 3 & 計 \\
\hline \multirow{4}{*}{$\begin{array}{l}\text { 採 } \\
\text { 岸 }\end{array}$} & 指 導 員 & 1 & 1 & & 2 \\
\hline & 落 口 番 & 1 & 1 & & 2 \\
\hline & 太 塊 割 & 1 & 1 & & 2 \\
\hline & カッタマン & 1 & 1 & & 2 \\
\hline & ケーブルマン & 1 & 1 & & 2 \\
\hline \multirow{4}{*}{$\begin{array}{l}\text { 員 } \\
\text { 請 } \\
\text { 負 }\end{array}$} & 面 文 保 & 24 & 24 & & 48 \\
\hline & ステーブル & 4 & 4 & & 8 \\
\hline & ステーブル & 2 & 2 & & 4 \\
\hline & 小 & 35 & 35 & & 70 \\
\hline \multirow{5}{*}{$\begin{array}{l}\text { 間 } \\
\text { 接 } \\
\text { 員 } \\
\text { 定 } \\
\text { 額 }\end{array}$} & 充 $\tau h$ & 5 & 5 & \multirow{4}{*}{2} & 10 \\
\hline & 鉄柱 管理 & 3 & 3 & & 6 \\
\hline & 材料運搬 & 1 & 1 & & 2 \\
\hline & 坔の 他 & 1 & 1 & & 2 \\
\hline & 小 & 10 & 10 & 2 & 22 \\
\hline \multicolumn{2}{|c|}{ 合 } & 45 & 45 & 2 & 92 \\
\hline
\end{tabular}

述のごとく長時間放置でをな ら状態であり, 石炭が比較的 軟らので, 切截前にカッペを 上げる事としているため，人 員配置恃分割責任持間方式

（定置制）在採用し，各持間 は 1 組 2 名とし $12 \mathrm{~m}$ を持っ ている。

作業は各方共切截より開始 し回収李で終了する方式であ る。作業工程表は第 8 図に示 क。

1) 切上り切截（天盤際切 截)

直接天盤が悪いため材料を 多量に使用するので, 早出に て材料配置安実施し, 採炭員 到着と同時に切截を開始する。 切上りの時のドラムの位置は 石崖の硬軟圭び天盤の状況に応じ上下させている。切 上り時間は切截面長 $145 \mathrm{~m}$ t $40 \mathrm{~min}(3.6 \mathrm{~m} / \mathrm{min})$.で，大 塊割，カッペ上げ待時間を除く純切截時間壮 $32 \mathrm{~min}(4.2$ $\mathrm{m} / \mathrm{min}$ ) である。

2) 切下り (下盤際切截) 積込

天盤切截終了後直ちにドーザープレートをセットして

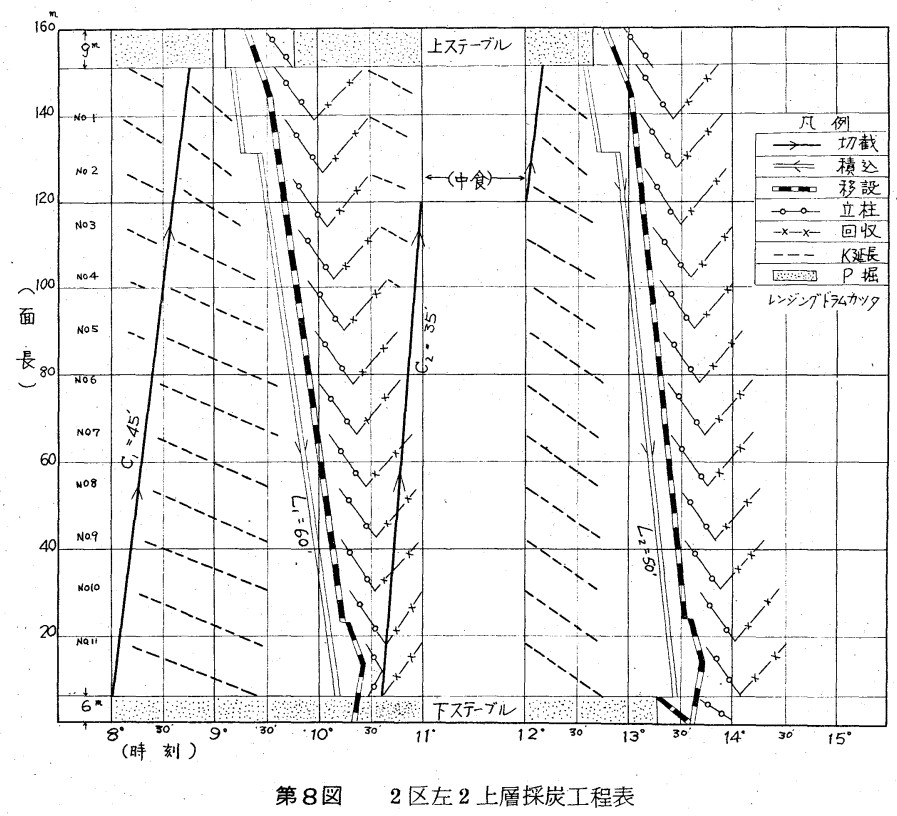

Vo 1.84 No. 965 ( $68^{-9}$ ) 
ドラムを下げ，D C Cトラフ床面より下 $0.1 \mathrm{~m}$ 交で切截し ながら切下る。

ドラムはスクリュー式なので, 切截された炭は自動的 にトラフに乗ぜられるが，残炭はドーザープレートによ り搔を集められる。

速度は産炭量により調節する。切下りに要する時間は 平均 $55 \mathrm{~min}(2.6 \mathrm{~m} / \mathrm{min})$ で, 純積込時間壮 $35 \mathrm{~min}(4.1 \mathrm{~m}$ $/ \mathrm{min}$ )である。切上りに比し時間支要するのは倒炭に上 る大塊の処理およびトラフよりの溢炭防止の速度調整の ためである。

3) 力ッペ延長

カッタスピードが大であるため，あらかじめ前方で 1 サイクル分のカッペ上げを実施しており，カッタ通過後 飞次払分の天盤切付けカッペ上げを行なう。

4) 移設

積込後は各自持間の残炭を掃除し，上部より移設する。 リターン部の移設はカッタが $30 \mathrm{~m}$ 下がうた時に実施す る。

移設を開始すると下盤の含煤がトラフに詰るので，D $\mathrm{C} \mathrm{C}$ 運転はりターン部の移設以外は停止しない。

5）立柱回収

移設が終了次第各自持間の立柱，回收孝行古ら。立柱 は 1 組で 18 〜 20 本を受持っており，1サイクル分の立 柱は $15 \sim 20 \mathrm{~min}$ を要す。払下部の組壮 2 回目切上りまで の作業密度が大きいのでその他人員を応援させている。

6) ステーブル

下ステーブルは 4 払分先行しピック掘であり，ステー ブルコンベヤをゲートD C C 亿接続している。支柱は格 子枠である。

上ステーブルは $0.7 \mathrm{~m}$ 先行のピック掘で払の D C C K手 積をしている。その他移設立柱等の付随作業がある。支 保汒千鳥枠である。

\section{6. 左 3上層ロングの実績}

同ロングはレンジングドラムカッタを使用するまで固 定式（ハリネズミ型）在使用したので両機の実績を第 5 表に示す。

\section{7. 問題点と改善事項}

1) 切截速度之産炭量

当初はドラムを最大限に上げて切截し, 最大速度 $9 \mathrm{~m}$ ／min 澾した。しかし切下り時に下記のごとを原因に よる作業工程の遅れが生じた。

1. 切下り時の産炭量が多く速度を速くでをない。

2. 跡山側への溢炭が多い。

3. D C Cの過負荷による停止が多い。

4. 残炭量が多い。

5. 倒炭の率が多く保安上好李しくない。

以上の理由で切上り時は，天艋の不良および吊炭個所
改造前
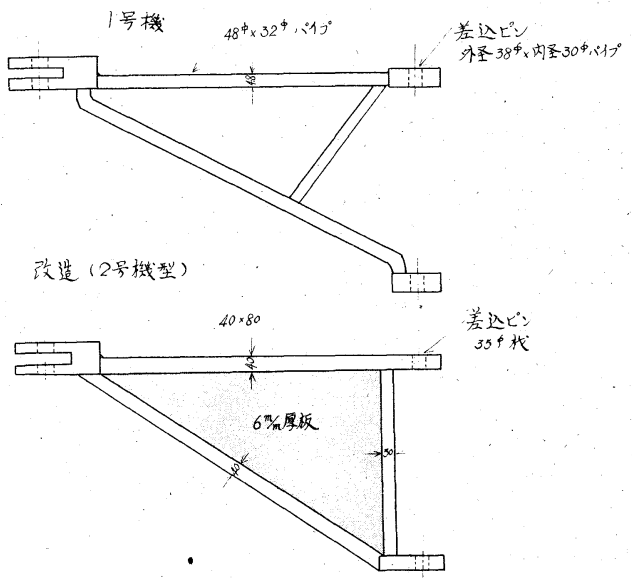

第9図ドーザープレートアーム

以外は極力ドラムを下げて使用し，切上り，切下り時の 産炭量のバランス在取るよ5にしている。なお切截速度 の增大によりカッペ上げが間に合わず, カッタの待時間 が生じたので，現在は 1 払分のカッペを前方で上げてい る。

2）切羽運搬機

当初は日立 $54 \mathrm{~W}$ 型 $(40 \mathrm{~kW} \times 2,31.8 \mathrm{~m} / \mathrm{min})$ 在使 用していたが; (1)運搬能力の限界内にカッタ速度が制限 される，(2)移設時に下盤の含煤による抵抗，(3)産炭量の 增加等により D C C の過負荷による停止時間が增加した ので，ウエストフアリヤ製 $\mathrm{P} \mathrm{F}-1 （ 42 \mathrm{~kW} \times 2.39 \mathrm{~m}$

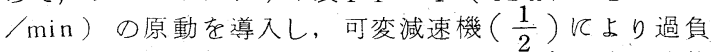
荷によるDCCの停止の問題は解決した。今後は切截能 率の向上のため，さらに運搬機の增強を検討中である。

3）ドーザープレート(第 9 図)

当初のプレートは， 1 枚板のものを使用し積込後の残 炭は約 $0.1 \mathrm{~m}$ であり，断層部および下盤の突起個所ではプ レートの下端が下盤に当たり抵抗となり，プレート取付 板の変形および取付ボルトの折損を生じたので, 取付板 およびアーム在補強した（第 9 図参照）。その後プレー トがスライドする構造とした結果, 残炭掃除は不要とな り,ショベリング中の倒炭およびフィードチエンの動摇 による保安上の問題子解決した。

4). 脱線防止プラケット(第 10 図)

アンギュラーガイド方式（第 7 図-1 参照）では, 当 初替動不円滑を生じ，スキットの先端がス・ピルプレート の先端に喰い込み，プレートを一度に数板脱落させ力ッ タの運行を不能にする故障が頻発したので，スキットの 厭みを $(30 \rightarrow 60 \mathrm{~mm})$ 改造した結果, 摺動状態が良く

第5表 採: 炭実 績 表 (2区左 3 上層ロング)

\begin{tabular}{|c|c|c|c|c|c|c|c|c|c|c|c|c|c|}
\hline \multirow[b]{2}{*}{ 月別 } & \multirow{2}{*}{$\begin{array}{l}\text { 稼 } \\
\text { 動 } \\
\text { 日 } \\
\text { 数. }\end{array}$} & \multicolumn{2}{|c|}{ 出 炭 $(\mathrm{t} /$ 月 $)$} & \multicolumn{3}{|c|}{ 切羽 条 件 } & 人 & \multicolumn{2}{|c|}{ 員（N） } & \multicolumn{2}{|c|}{ 能 (精炭 $\mathrm{t} /$ 人) } & \multirow{2}{*}{$\begin{array}{l}\text { 能 率 } \\
\text { 上昇率 } \\
\text { (総体) }\end{array}$} & \multirow{2}{*}{ 使用機械 } \\
\hline & & 原 炭 & 精 炭 & 面長 m & 傾 斜 ${ }^{\circ}$ & 山文m & 採 炭 & その他 & 計 & 採 炭 & 総 体 & & \\
\hline & 26 & 24,171 & 15.512 & 162 & $18 \sim 20$ & 2.37 & 79 & 18 & 97 & 7.55 & 6.12 & 78 & ハリネズミ \\
\hline$" 10$ & 26 & 33,592 & 20,293 & 161 & $\prime \prime$ & 2.45 & 69 & 35 & 104 & 11.27 & 7.85 & 100 & " \\
\hline "I. 11 & 25 & 39,530 & 22,347 & 163 & $" \prime$ & 2.43 & 69 & 39 & 108 & 12.89 & 8.28 & 106 & レンジ \\
\hline "I 12 & 26 & 39,542 & 23.330 & 165 & $\prime \prime$ & 2.46 & 73 & 39 & 112 & 12.32 & 8.00 & 102 & ! \\
\hline $43 . \quad 1$ & 25 & 42,678 & 23.714 & 157 & " & 2.50 & 84 & 21 & 105 & 11.32 & 9.04 & 115 & " \\
\hline "I & 24 & 40,320 & 24,690 & 155 & " & 2.52 & 72 & 19 & 91 & 14.23 & 11.31 & 144 & $\prime \prime$ \\
\hline$" \prime$ & 26 & 42,194 & 24,952 & 156 & " & 2.50 & 70 & 22 & 92 & 13.69 & 10.45 & 133 & \\
\hline
\end{tabular}


改造前
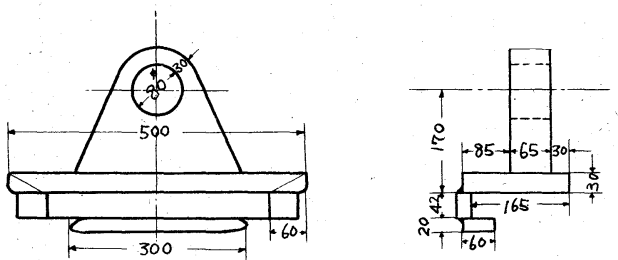

改造（寸法記入は改造部）

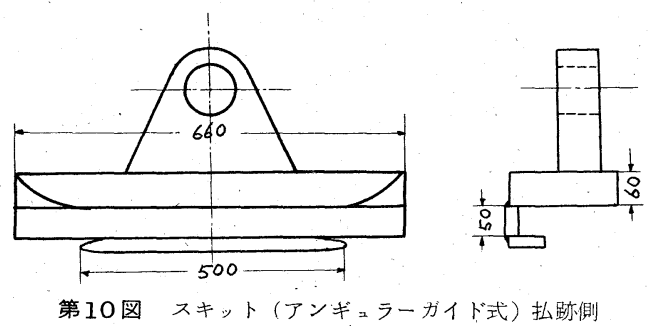

なった。しかしスキットとプレートがなじむまではスピ 一ドを上げる事がてをない。

2 号機よりチューブラガイド方式（第 7 困-2）在採 用七好結果を得ている。

5）フイードチエン繁張装置

従来ゆ両端固定方式は, チエンが緩み, ホーレイジの 巻取スプロケットで，スラックサイドのチエンの離れが 悪く，力ッ夕の運行が円滑に行か好場合があり，積込時 断層，馬の背部を通過の際にチエンのはね上りによる保 安上の問題点が生じていたが, 緊張装置取付けにより負 傷者が減少し, 好結果を得ている。

6) ケーブルの管理

イ）クランプ部の損傷

従来方向変換による曲げの繰返し, およびカッタ辇引 力による高張力のための操作線の断線が考えられるので, カッタ走向変換 60 サイクルごとに $600 \mathrm{~mm}$ ケーブルを 切詰めていたが, 取付口をトランペット型とし切詰めは 120 サイクル毎で良くなった。李たプラグ引込方式を, 分岐図接続方式にするととにより，切詰め作業時間が㶾 縮された。

ロ） スピルプレートの改善

ケーブルの挾み，敷込み，引掛け，および発破等によ る損傷の事故が比較的多かったので（1 切羽1件／月）, スピルプレートを, 従来の第 11 図在第 7 図 の如く幅広 とし, 傾斜板在つけた結果事故は半減した。

八）ケーブルハンドラー

2 号機よりケーブルハンドラーを採用し，前記のケー ブル損傷による事故は皆無となったが，下記問題点があ るので検討が必要である。

(1) 急傾斜の場合自走する。経験によると傾斜の限界 は 18 度である。断蟹出現時壮傾斜が $22^{\circ} \sim 27^{\circ}$ になる ので応急詨策として，スピルプレートの底にゴム板を敷 込み，千エンに消火ホース巻を自走を防止したが，プ レート上のズリはけ不良となり，ズリの抵抗によりピン の摩耗ならびに脱落の欠点が生じた。

(2) カッタが全面長運行しないで途中反転すると, 二 重, 三重のループが生じハンドラーがプレートより脱落 する事がある。

(3) 払面長が変化する場合，および払面がゲートに直 角でない場合には，常時ケーブの折返し部を移動させね

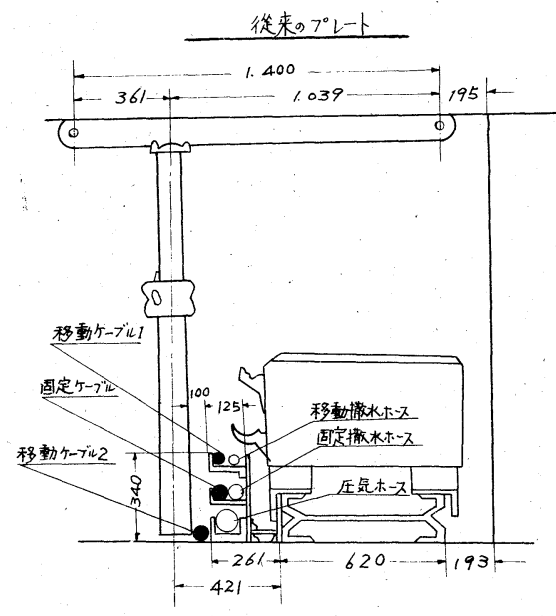

第11図

ば，二重，三重のループが生じる。

(4)上記の場合はそれぞれケーブル監視人が必要であ る。

7) その他

(1) ピック。2号機よりセットボルト式をロックフア スト式としピックの脱落は減少した。

(2) 油止シフター。 3 号機より NKKD-75 型（推力 $6 \sim 12 \mathrm{t}$ ) 在採用し移設時間の短縮を計った。

(3) 機体調整油圧ジャッキ。2 号機よ.り使用している。

\section{8. 固定ドラムカッタとの比較}

従来の固定式と比較し, アイコフ製レンジングカッタ の長所，および固定式の不利な点は下記のでとくである。

1) レンジングカッタ

1）いかなる稼行丈でも切截でをる。

口）稼行丈在 2 分して切截するので, 産崖量を一定に する事ができる。したがって倒崖等のピークが少ない。

八）吊炭落しが容易である。

二）断層，天盤不良個所等切截面の障害を，上下サン ピングである程度逃る事がでをる。

ホ）トラフ床面下 $0.1 \mathrm{~m}$ で下盤切截が可能で下盤調整 が容易である。

へ）大塊の出る率が少索ら。

ト）プラウが不要で下部ステーブルが短縮でをる。

チ）ドーザープレートによる積込後の残嵌が少なくシ ヨベリングによる掃除は極く僅かである。

リ）ドーザープレートは，蝶番式でセットが簡単で， 準備時間を要しない。

ヌ）押し切が可能で面直しが便利である。

ル）チューヴラガイド式で機体の脱線がない。

ヨ）出力が大なるため, 章引力が強く、 スピードがあ る。

ワ）スクリニードラムなので炭塵発生量が少ない。

2)，固定式（ハリネズミ型）

イ）厚層になるに従って切截に時間克要する。

ロ）倒炭が多く塊崖割によるDC C 運転の停止が多々。

八）切截時に多量の炭が出るので, D C C の過負荷に よる停止がある。切戴，積迂の産炭量のバランス調節が でをない。

二）積込の時馬の背があると，プラウが浮を舟底の所 
では下盤に突をささる。

ホ）残炭量が多くショベリングに時間を要す。

へ）押切がでをなっ。

ト) 払面が曲っている時, 馬の背が強い時, 断層部, 払が卸向の時に脱線が多い。

チ）制引力が弱い（第 12 図参照）。

リ）機体と,トラフの間隙が少ないので, 上添側より くる炭がカッターの前で溢れ，切截が遅れる。

又) 炭塵発生量が多い。

\section{9. 今後の課 題}

1) カッ夕切截能率を高くするため, 払運搬能力の増 強を計る。

2）支保作業のスピード化。カッタ切截速度が速くな るに従って, 支保もこれに追従して行かねばならない。 立柱回収を一定の限られた人員で行ならには限度がある。

3) ステーブル採炭の機械化。将来のサイクル增加を 目標とするには，ステーブル採炭の機械化をしなければ ならない。

4）リターン部の移設を運転停止をしないで行なう。

\section{0. 結 言}

当砿は稼行丈の増大に伴い, 従来のハリネズミ型では,

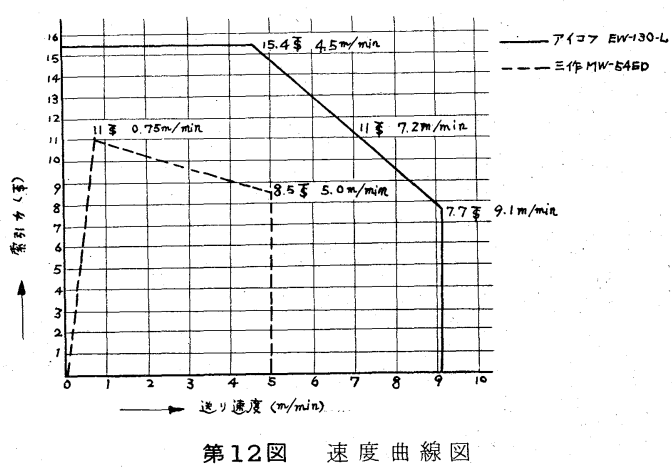

4 サイクル /日, 切截確保が困難になってをたので, 高 出力のレンジングドラムカッタを導入した結果, 4 サイ クル/日の確保が容易になった。

アイコフ製レンシシングドラムカッタは, 前述の長所が あり, 使らやすい機械である。当面はこの特徵を充分に 発揮させ，サイクル増加を目標に作業を進めている。今 後ダブルドラムの導入を検討し, 一切羽多量出炭, 切羽 進行度のアップと, 高能率化に努力を傾注してゆく考え である。

\section{〈製品技術紹介〉}

\section{三 井レンジン}

\section{1. 緒}

䌘社製レンジングドラムカッタは, 昭和 41 年より製 作を開始し，現在約 20 台が稼動している。

型式は，ドラムを機体中央に配置した 8095 型，ドラ 厶老機体後方に配置した 8090 型, 従来の旋回式へリカ ルドラムカッタのカッタヘッドのみレンジングドラムと取 り換えた 5490 型, それになおホーレージ強化した 5590 型がある。出力も $90,120,150,200 \mathrm{~kW}$ とど のよらな炭層条件にも適応でをるよら多種のシングルお よびダブルのレンジングカッタを製作している。

ここに紹介する 6060 型レンシングドラムカッタは山 丈 $1.3 \sim 2.0 \mathrm{~m}$ の中層を対象亡し機体を小型にをとめた新 製品で, 本年 7 月初めから三井三池宮浦鉱で好調に稼働 している。い菓で使用していた旋回型へリカルドラム のように天盤ぎわを発破する必要はなく，松岩もドラム を上下して容易にかわすととができる。そのらえに往復 採炭がでさるので, 後続作業がスムーズに行なえ, 能率 もアップして好評である。

\section{2. 仕}

\section{様}

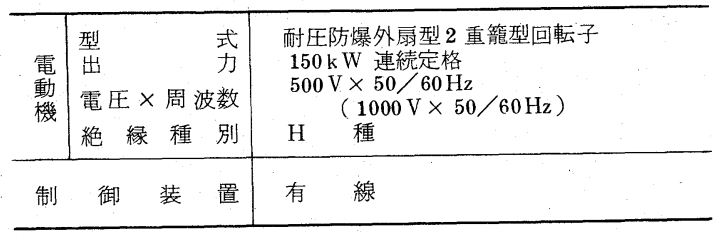

\section{グ ドラム カ ッ タ}

\section{三 輪}

了*

\begin{tabular}{|c|c|c|}
\hline $\begin{array}{l}\text { ホ } \\
1 \\
\text { レ } \\
1 \\
\text { 部 }\end{array}$ & 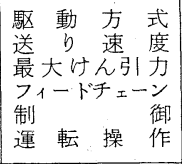 & $\begin{array}{l}\text { 油庄駆動 } \\
0 \sim 10 \mathrm{~m} / \mathrm{min} \\
15,000 \mathrm{mg} \\
18 \phi \times 64 \mathrm{~m} / \mathrm{P}(20 \phi \times 64 \mathrm{P}) \\
\text { 自動調速装置付 } \\
\text { 側面操作 }\end{array}$ \\
\hline $\begin{array}{l}\text { カ } \\
\% \\
\text { タ } \\
\text { 人 } \\
\text { \% } \\
\text { ド } \\
\text { 部 }\end{array}$ & $\begin{array}{l}\text { ドラム軸回転数 } \\
\text { ドラム上下方式 } \\
\text { ドラム上下角度 } \\
\text { ドラム上下時間 } \\
\text { ドラム位置固定 } \\
\text { 油 圧 装 置 }\end{array}$ & $\begin{array}{l}50 \mathrm{~Hz} \quad 78 \mathrm{rpm}(70 \sim 87 \text { 間変更可能 }) \\
60 \mathrm{~Hz} 77 \mathrm{rpm}(68 \sim 87 \text { 間变更可能 }) \\
\text { 油庄シリンダ駆動方式 } \\
+60^{\circ} \sim-20^{\circ} \\
1 \text { 分以内 } \\
\text { 逆止弁による油圧シリンダ固定方式 } \\
\text { ギヤーポンプ }\end{array}$ \\
\hline $\begin{array}{l}\text { ド } \\
\text { ラ } \\
\text { ム } \\
\text { 部 }\end{array}$ & 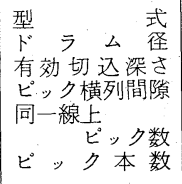 & $\begin{array}{l}\text { ヘリカルドラム（押込サンピング付） } \\
950 \mathrm{~mm}(1100,1300,1500 \mathrm{~mm}) \\
600 \mathrm{~mm}(600 \sim 750 \mathrm{~mm}) \\
14 \mathrm{~mm}(14 \sim 28 \mathrm{~mm}) \\
1 \text { 本 }(\text { 硬質炭 } 2 \text { 本 }) \\
\text { 約 } 55 \text { 本 }(55 \sim 80 \text { 本 })\end{array}$ \\
\hline & 込ガイド板 & 水平旋回型（油压ジャッキ内藏） \\
\hline $\begin{array}{l}\text { ス } \\
\text { キ } \\
\text { ド }\end{array}$ & $\begin{array}{l}\text { 型 } \\
\text { スキ式 } \\
\text { スキッド上下ド } \\
\text { ストローク } \\
\text { シャッキカ量 }\end{array}$ & $\begin{array}{l}\text { 炭壁側 } 2 \text { 個固定．鉄柱僋 } 2 \text { 個油圧 } \\
\text { シャッキ調整 } \\
4 \text { 点単独スキッド } \\
+100 \sim-40 \mathrm{~mm} \\
\text { 押上力 } \quad 6,500 \mathrm{~kg}\end{array}$ \\
\hline 適 & 応山文 & $\begin{array}{l}1.3 \sim 2.0 \mathrm{~m}(\text { ドラム, レンジングアーム, } \\
\text { スキッドを取り替えて最高 } 2.8 \mathrm{~m} \text { まで可 } \\
\text { 能) }\end{array}$ \\
\hline 盤 & 下 切 削 & $50 \mathrm{~mm}$ \\
\hline & $\begin{array}{c}\text { 体総 重 } \\
\text { ジン量 } \\
\text { ダン プ } \\
\text { ダ }\end{array}$ & $\begin{array}{l}\text { 約 } 9,000 \mathrm{~kg} \\
\text { 約 } 12.500 \mathrm{~kg}\end{array}$ \\
\hline
\end{tabular}

* 株式会社三井三池製作所 技術部調查役 